OPEN ACCESS

Edited by:

Hongyue Dang,

Xiamen University, China

Reviewed by:

Mansha Seth Pasricha,

Rutgers University-The State

University of New Jersey,

United States

Peter Croot,

National University of Ireland Galway,

Ireland

*Correspondence:

Coco Koedooder

koedooder@obs-banyuls.fr;

cocokoedooder@gmail.com

Specialty section:

This article was submitted to

Aquatic Microbiology,

a section of the journal

Frontiers in Marine Science

Received: 15 June 2018 Accepted: 30 October 2018 Published: 21 November 2018

Citation:

Koedooder C, Guéneuguès $A$,

Van Geersdaële R, Vergé V,

Bouget F-Y, Labreuche $Y$,

Obernosterer I and Blain S (2018) The

Role of the Glyoxylate Shunt in the Acclimation to Iron Limitation

in Marine Heterotrophic Bacteria.

Front. Mar. Sci. 5:435.

doi: 10.3389/fmars.2018.00435

\section{The Role of the Glyoxylate Shunt in the Acclimation to Iron Limitation in Marine Heterotrophic Bacteria}

\author{
Coco Koedooder ${ }^{1 *}$, Audrey Guéneuguès ${ }^{1}$, Rémy Van Geersdaële ${ }^{1}$, Valérie Vergé', \\ François-Yves Bouget ${ }^{1}$, Yannick Labreuche ${ }^{2,3}$, Ingrid Obernosterer ${ }^{1}$ and Stéphane Blain ${ }^{1}$
}

'Laboratoire d'Océanographie Microbienne, Centre National de la Recherche Scientifique, Sorbonne Université, Banyuls-sur-Mer, France, ${ }^{2}$ Unité Physiologie Fonctionnelle des Organismes Marins, Institut Français de Recherche pour l'Exploitation de la Mer, Brest, France, ${ }^{3}$ Integrative Biology of Marine Models, Centre National de la Recherche Scientifique, Sorbonne Université, Roscoff, France

Iron $(\mathrm{Fe})$ is an essential element for marine microbial growth but is present in trace amounts $(<0.1 \mathrm{nM})$ in surface waters of the ocean. In heterotrophic bacteria, Felimitation particularly impacts ATP production as Fe is an essential co-factor of enzymes involved in the electron-transport chain as well as the tricarboxylic acid (TCA) cycle. Fe-limitation can therefore drastically reduce both bacterial growth and respiration, consequently affecting the efficiency of organic carbon remineralization. Heterotrophic bacteria possess various strategies to cope with Fe-limitation. In the present study we tested the hypothesis that the induction of the glyoxylate shunt can represent one such strategy. Genetic approaches were used to gain insight into the potential role the glyoxylate shunt may have in alleviating Fe-stress using the gammaproteobacterium, Photobacterium angustum S14. A recombinant bioluminescent reporter of $P$. angustum S14 (icl-luc) revealed a strong and significant increase in the expression of isocitrate lyase (icl), a key enzyme within the glyoxylate shunt, when cells were subjected to strong Fe-limitation. Although the growth and respiration rates decreased for both the wildtype and an icl knockout mutant $(\Delta \mathrm{icl})$ under strong Fe-limitation, they were $\pm 30 \%$ lower for $\Delta \mathrm{icl}$ as compared to the wildtype. Complementation of $\Delta \mathrm{icl}$ restored the growth and respiration rates to those observed in the wildtype, further confirming the importance of the glyoxylate shunt under strong Fe-limitation. Due to the ubiquitous nature of the glyoxylate shunt within marine bacteria, our results lead us to propose this pathway as an important acclimation strategy for marine heterotrophic bacteria that are subjected to Fe-limitation.

Keywords: iron, Fe-limitation, Photobacterium angustum S14, glyoxylate shunt, isocitrate lyase

\section{INTRODUCTION}

Since the initial experiments of Martin and Fitzwater (1988) and the resulting Fe-hypothesis (Martin, 1990), it has been well established that in High Nutrient Low Chlorophyll (HNLC) regions, the constraint in microbial growth is dictated by the low bioavailable Fe-levels found in their surface waters. Current research on Fe-limitation has primarily focused on photosynthetic plankton due to their major contribution to the biological carbon pump (Ducklow et al., 2001). By contrast, less attention has been given to the role of Fe-limitation on heterotrophic bacteria 
which plays a significant role in the biogeochemical cycle of carbon through their role as principal remineralizers of dissolved organic matter (Azam et al., 1983).

It is estimated that around $90 \%$ of the total cellular uptake of Fe in heterotrophic bacteria is utilized in the I, II, III, and IV complexes of the electron transport chain where it serves as an important co-factor in various Fe-redox enzymes such as cytochromes and the Fe:S clusters (Holms, 1996; Tortell et al., 1999; Alberts et al., 2002; Andrews et al., 2003; Almaas et al., 2005). Consequently, under Fe-limitation, heterotrophic bacteria are particularly affected in the efficiency in which they can produce ATP (Tortell et al., 1996), a molecule widely regarded as the most important energy-transfer molecule within the cell (Knowles, 1980).

Heterotrophic bacteria may harbor a certain physiological plasticity when subjected to environmental stressors such as Fe-limitation. This was first shown in a study where the cellular $\mathrm{Fe}: \mathrm{C}$ ratio for several heterotrophic bacterial isolates changed depending on the $\mathrm{Fe}$-concentrations present in the environment (Tortell et al., 1996). Studies further reported changes in the regulation of metabolic pathways, including the TCA cycle, glycolysis and oxidative phosphorylation in response to Fe-limitation (Oexle et al., 1999; Shakoury-Elizeh et al., 2010; Fourquez et al., 2014). In one such study, Fourquez et al. (2014) revealed the upregulation of the glyoxylate shunt under Fe-limitation for a coastal strain, gammaproteobacterium Alteromonas macleodii. The increased expression of isocitrate lyase, a gene involved in the glyoxylate shunt, was further noted in experiments conducted by Smith et al. (2010) using various "Candidatus" Pelagibacter ubique strains and in a field study of Beier et al. (2015) for members of the SAR11 clade. Although, these observations suggest that the glyoxylate shunt is a possible acclimation strategy for heterotrophic marine bacteria in dealing with Fe-limitation, the strong association of the glyoxylate shunt toward the metabolism of certain carbon compounds makes it difficult to directly ascertain its induction with Fe-limitation. More recently, however, the induction of the glyoxylate shunt under both Fe-limitation and oxidative stress was also observed in the non-marine bacterium Pseudomonas aeruginosa (Ahn et al., 2016; Ha et al., 2018). Altogether, these results sparked interest in whether the induction of the glyoxylate shunt could serve as a metabolic acclimation strategy for bacteria subjected to Fe-limitation in a marine context.

The glyoxylate shunt is a two-step metabolic pathway found in aerobic bacteria that serves as an alternative route within the classic tricarboxylic acid (TCA) cycle (Figure 1; Kornberg and Krebs, 1957; Kornberg, 1966). Its primary function is to circumvent the carbon dioxide $\left(\mathrm{CO}_{2}\right)$ production step within the TCA cycle in order to drive the metabolism of fattyacids or two carbon-compounds such as acetate toward the production of oxaloacetate, which can further serve as a precursor for gluconeogenesis. The metabolism of fatty-acids and acetate without the presence of the glyoxylate shunt is simply catabolic and the net production of carbohydrates is not possible due to the irreversible production of pyruvate to acetyl coenzyme-A under glycolysis. For this reason, the induction of the glyoxylate shunt is associated with anabolic pathways. More importantly, the glyoxylate shunt bypasses the NADH producing steps which is required within the electron transport chain in the production of ATP. Because the efficiency of the electron transport chain is severely hindered under Fe-limitation, we hypothesize that redirecting a cell's metabolism away from Fe-limiting steps by means of the glyoxylate shunt could be an important manner in which a cell can increase its metabolic efficiency under Fe-stress.

The objective of the present study was to investigate, for the first time in a marine context, whether the induction of the glyoxylate shunt is indeed directly related to Fe-limitation and whether its induction can affect bacterial growth and respiration rates. Through the use of genetic tools, the role of the glyoxylate shunt under Fe-limitation was elucidated via the construction of both a luminescent bioreporter (icl-luc), a knockout $(\Delta \mathrm{icl})$ and its complement $(\mathrm{icl}+)$ of the isocitrate lyase gene in the model organism Photobacterium angustum S14. Isocitrate lyase (icl) was the chosen gene of interest as it is a key enzyme within the glyoxylate shunt. The genome of P. angustum S14 has been sequenced and an extensive physiological data set is already established (Lauro et al., 2009), making it a sound candidate for our experimental setup. P. angustum S14 is a gramnegative gammaproteobacterium of the Vibrionaceae family, originally isolated at $1 \mathrm{~m}$ surface depth in Botany Bay, Australia in 1981 (Humphrey et al., 1983) and it is currently classified as a copiotrophic, coastal bacterium (Humphrey et al., 1983; Williams et al., 2011). Experiments on the bioreporter icl-luc tested the expression of $i c l$ under various levels of Fe-limitation and different sources of organic carbon, while comparative experiments between the wildtype, $\Delta \mathrm{icl}$ and its complement $(\mathrm{icl}+)$ aimed to determine whether $i c l$ induction allowed a physiological advantage in terms of growth or respiration rates.

\section{MATERIALS AND METHODS}

\section{Strains and Media}

The P. angustum strain S14 was provided by Prof. S. Kjelleberg (UNSW, Sydney, NSW, Australia) and stored in the Microbial Observatory of the Laboratoire Arago (MOLA) culture collection $\left(\mathrm{BBCC} 745^{1}\right)$. P. angustum S14 cultures were grown out of cryopreservation and maintained in either ZoBell medium and ZoBell agar (Oppenheimer, 1952) or in Luria-Bertani (LB) medium and LB agar (Bertani, 1951) with the addition of $\mathrm{NaCl}$ $(0.5 \mathrm{M})$, at $20^{\circ} \mathrm{C}$. The Escherichia coli strains $\Pi 3813$ and $\beta 3914$, were, respectively, used as plasmid hosts for amplification and transformation by bacterial conjugation (Le Roux et al., 2007) and were grown in $\mathrm{LB}$ medium and $\mathrm{LB}$ agar at $37^{\circ} \mathrm{C}$. When necessary, chloramphenicol $(\mathrm{Cm}), 5 \mu \mathrm{g} / \mathrm{mL}$ for $P$. angustum S14 and $25 \mu \mathrm{g} / \mathrm{mL}$ for $E$. coli strains, thymidine $(0.3 \mathrm{mM})$ and diaminopimelate $(0.3 \mathrm{mM})$ were added as supplements to the medium. Induction of the $\mathrm{P}_{B A D}$ promoter was achieved through the addition of $0.2 \% \mathrm{~L}$-arabinose to the growth medium. Conversely, repression was obtained by the addition of $1 \% \mathrm{D}$ glucose. All strains (wildtype (wt), $\Delta \mathrm{icl}$, icl+, and icl-luc) were taken out of cryopreservation and plated on ZoBell medium at

\footnotetext{
${ }^{1}$ https://collection.obs-banyuls.fr/
} 


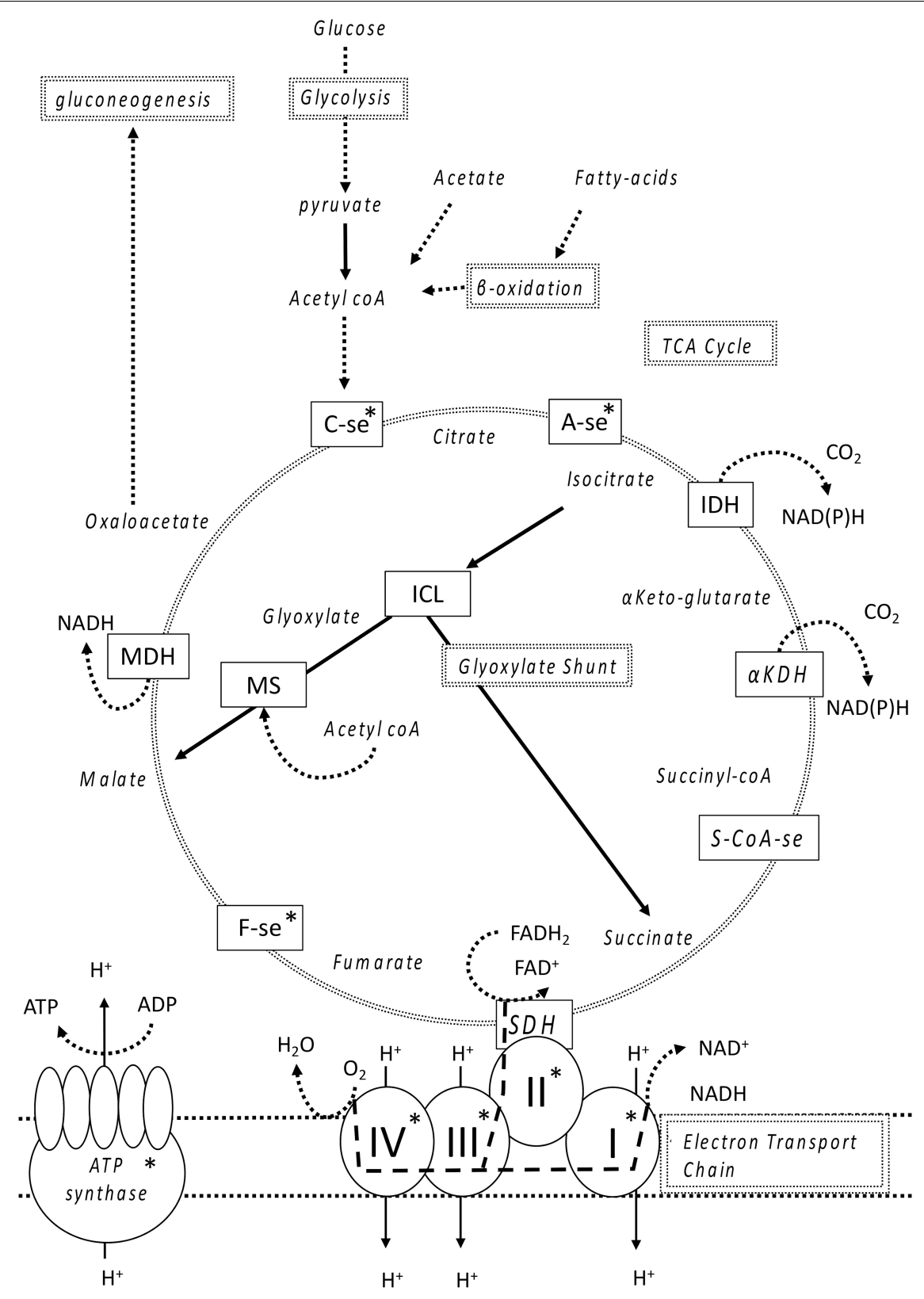

FIGURE 1 | Simplified overview of the TCA cycle and electron transport chain. Double lined boxes indicate the major components of metabolism, single lined boxes are the enzymes utilized and indented text are molecules and metabolites produced by those enzymes. Briefly, glucose undergoes glycolysis for the formation of pyruvate which is converted to acetyl COA that, together with oxaloacetate enters the TCA cycle through the formation of citrate. Acetate and fatty acids are converted to acetyl coA but the biosynthesis of carbohydrates (using malate and oxaloacetate) can only occur upon entering the glyoxylate shunt (dark straight lines) allowing the formation of oxaloacetate, which can then undergo gluconeogenesis, as the pathway from pyruvate to acetyl coA is irreversible. The glyoxylate shunt bypasses the production of $\mathrm{CO}_{2}$ further down the TCA cycle forming both succinate and malate. Electrons from either $\mathrm{NADH}$ or FADH $\mathrm{H}_{2}$, respectively, enter the electron transport chain either through complex I or II (large dashed lines) resulting in different possible quantities of ATP produced. Take note that SDH and Complex II are the same molecule. Fe-containing enzymes within the TCA-cycle and electron transport chain are marked with an asterisk. The following abbreviations were used for each enzyme: C-se, citrate synthase; A-se, aconitase; IDH, isocitrate dehydrogenase; ICL, isocitrate-lyase; aKDH, alpha keto dehydrogenase; S-coA-se, succinyl coA synthase; SDH, succinate dehydrogenase; F-se, Fumarase; MS, malate synthase; MDH, malate dehydrogenase; $\mathrm{Q}$, quinone, and the roman numerals I, II, III, IV, indicate the four complexes of the electron-transport chain.

$20^{\circ} \mathrm{C}$ for a period of $48 \mathrm{~h}$ at room temperature. Colonies were subsequently picked and transferred in $5 \mathrm{~mL}$ of liquid Aquil medium (see below) for $24 \mathrm{~h}$ before being grown in larger batch cultures of $12 \mathrm{~mL}$. Prior to the start of the experiment, batches were refreshed at least $3 \times(25 \mu \mathrm{L}$ of culture was transferred to a fresh $12 \mathrm{~mL}$ batch of Aquil medium every 2 days) in order to 
remove any traces of $\mathrm{Fe}$ and carbon that could be carried over from the ZoBell medium.

\section{Genetic Tools}

Deletion of the icl gene was performed by allelic exchange using the pSW7848T suicide vector, as described previously (Le Roux et al., 2007; Val et al., 2012). Briefly, two independent PCR amplifications of the upstream and downstream regions (500 bp) that encompass the icl gene were performed using primer pairs 11013-3/11013-4 and 11013-5/11013-6, respectively (Supplementary Table 1). An inside-out PCR was conducted on the R6K based suicide vector pSW7848T using primer pair 190613-21/190613-21. After purification and quantification, PCR fragments were cloned into the pSW7848T suicide vector as described previously (Lemire et al., 2015) and transferred by conjugation from the donor $E$. coli to the recipient $P$. angustum S14 by a filter mating procedure as described previously (Le Roux et al., 2011) with a donor/recipient ratio of 1:10 ml. Subsequently, the first and second recombination lead to the integration and elimination of pSW7848T which was, respectively, selected for on $\mathrm{Cm} /$ glucose and arabinose containing media.

The icl gene for the construction of the complement (icl+) was derived from PCR-amplification from the genomic DNA of the wt strain and cloned in ApaI/XhoI sites of the pMRB plasmid (Le Roux et al., 2011) resulting in its constitutive expression using a $\mathrm{P}_{\text {LAC }}$ promoter (Lemire et al., 2015). Conjugation between E. coli and $P$. angustum $\mathrm{S} 14$ were performed at $30^{\circ} \mathrm{C}$ as described above.

\section{Isocitrate Lyase Bioreporter}

A bioreporter for the expression of $i c l$ (icl-luc) was constructed in a method similar to that of the construction of $\Delta \mathrm{icl}$ with the exception that the $i c l$ gene was fused with the bioluminescent reporter gene luciferase within the same reading frame and the removal of the $c c d B$ toxin gene from the pSW7848T suicide vector. A PCR of $i c l$ was performed using the primer pair For190314-ICL and Rev190314-ICL while a PCR of luciferase occurred using the primer pair For190314-luc and Rev190314luc. An inside-out PCR of the pSW7848T vector (Val et al., 2012) was done using the primer pair For190314-p-aceBA and Rev190314-p-aceBA to remove the $c c d B$ toxin gene from the original construct (Supplementary Table 1). After homologous recombination of the plasmid into $P$. angustum S14, expression of the native gene is coupled with the expression of the reporter gene. A second recombination, which removes the plasmid and causes the restitution of the wt is prevented by $\mathrm{Cm}$-selection. Iclluc was always grown on plates or liquid medium containing the antibiotic $\mathrm{Cm}(5 \mu \mathrm{g} / \mathrm{mL})$. Icl-luc, $\Delta \mathrm{icl}$ and icl+ were placed in cryopreservation using glycerol $(35 \%)$ at $-80^{\circ} \mathrm{C}$.

\section{Trace Metal-Free Conditions}

All experiments were conducted under trace metal clean conditions in a clean room (class 10000) and under a laminar flow hood (ADS class 100). All plastic materials were made trace metal free by soaking them for $24 \mathrm{~h}$ in $10 \% \mathrm{HCl}$ followed with an ultrapure water bath (18.2 M $\Omega$, Elga) containing a $0.2 \mu \mathrm{m}$ final filter (Thermo Fisher Scientific) for another $24 \mathrm{~h}$. Plastic flasks dedicated to the culture experiments were additionally microwaved $3 \times$ at $750 \mathrm{~W}$ until boiling. All plastic materials were placed under the laminar flow hood to dry and sterilized by UV light (30 $\mathrm{min}$ ) before use.

All batch cultures were maintained in single-carbon Aquil medium of glucose $(6 \mathrm{mM}[\mathrm{C}])$ and in Fe-replete conditions $(5.4 \mu \mathrm{M})$. Aquil medium (Price, 1989), one of the most common sea water media used in trace metal-free experiments, is a modified version of the medium prepared by Morel et al. (2008). Synthetic Ocean Water (SOW), was first passed through a column containing a Chelex 100 resin (Bio-Rad) in order to remove all trace metals including Fe (Davey et al., 1970). The different carbon sources were individually chelexed to form stock solutions of $3 \mathrm{M}[\mathrm{C}]$ and were added later on in experiments as single carbon sources. SOW was filtered $(0.2 \mu \mathrm{m})$ and further sterilized by microwaving it $3 \times$ at $750 \mathrm{~W}$ until boiling before the addition of nutrients, vitamins and metals all filtered through a $0.2 \mu \mathrm{m}$ syringe Acrodisc filter (Pall Corporation). A stock solution of $\mathrm{FeCl}_{3}$ was allowed to complex with EDTA at a 1:1 ratio. Fe-EDTA was subsequently filtered $(0.2 \mu \mathrm{m})$ and added to the Aquil medium (5.4 $\mu \mathrm{M}$ final concentration). Bacteria were grown in batches and transferred into new medium every 2 days with a starting dilution of approximately $1.8 \times 10^{4}$ cells $\mathrm{mL}^{-1}$.

Prior to the start of each experiment, bacterial strains (either wt, $\Delta \mathrm{icl}$, icl+, or icl-luc), were acclimated for $24 \mathrm{~h}$ in a fresh batch of Aquil medium (see above) at $20^{\circ} \mathrm{C}$ with a stirring rate of $110 \mathrm{rpm}$. Icl-luc was grown with the addition of luciferin $(250 \mu \mathrm{M}$, final concentration). Bacteria were fixed in formaldehyde (2\%) and stained with SYBR Green I ( $1 \mathrm{~h})$ prior to measuring cell counts using a Becton Dickinson Accuri C6 flow cytometer (Marie et al., 1997). Bacteria were subsequently transferred into Aquil media with a given carbon and $\mathrm{Fe}-$ concentration at a starting abundance of $1.8 \times \times 10^{5}$ cells $\mathrm{mL}^{-1}$. All bacteria were grown in the dark in order to prevent any possible interaction with the induction of proteorhodopsin; a potential photoheterotrophic trait of $P$. angustum S14 (Palovaara et al., 2014; Pinhassi et al., 2016).

\section{Growth and Respiration Rates}

Growth and respiration rates were derived from continuous dissolved oxygen $\left(\mathrm{O}_{2}\right)$ measurements in batch cultures using a SensorDish reader (Presens) equipped with 24 glass vials of $4.8 \mathrm{~mL}$ containing non-invasive $\mathrm{O}_{2}$ sensors (OxoDish, Supplementary Figure 1). The entire setup was placed in an incubator at a constant temperature of $20^{\circ} \mathrm{C} . \mathrm{O}_{2}$ concentrations were derived from 10-min averages of quenched fluorescence measurements taken every $30 \mathrm{~s}$ over a period of $24 \mathrm{~h}$. Vials were calibrated using a two-point protocol. A $0 \mu \mathrm{M} \mathrm{O}_{2}$ solution was prepared with a $1 \% \mathrm{Na}_{2} \mathrm{SO}_{3}$ in Milli-Q water. A $100 \%$ oxygenated solution was prepared by bubbling air at a constant temperature for $2 \mathrm{~h}$ in Milli-Q water and left overnight with the lid open to allow exchange with air. $\mathrm{O}_{2}$ concentrations in Aquil medium were further corrected for by taking into account the salinity of the medium $(S=35)$ using the solubility equation of Garcia and Gordon (1992). Blanks consisting of filtered Aquil medium $(0.2 \mu \mathrm{m})$ were used to monitor for any significant drift from the 
$\mathrm{O}_{2}$ sensors for the entire duration of the experiments $(24 \mathrm{~h})$. A time window was carefully chosen in order to capture the exponential phase. Care was taken to avoid the inclusion of any metabolic switches (Oldfelt, 1942; Wolfe, 2005). An average of every $10 \mathrm{~min}$ was taken to derive the growth and respiration rates from the selected $\mathrm{O}_{2}$ measurements. During the exponential growth phase, we assume that both the growth rate $\left[\mu\left(s^{-1}\right)\right]$ and the respiration rate per cell $\left[\mathrm{R}_{\text {cell }}\left(\mathrm{fmol} \mathrm{cell}{ }^{-1} \mathrm{hr}^{-1}\right)\right]$ are constant. This assumption was further verified by looking at the agreement between experimental data and model fitting (Supplementary Figure 2). Changes in $\Delta \mathrm{O}_{2}$ concentrations over time were derived from the integral of the rate of change in $\mathrm{O}_{2}$ over time using the following equation below:

$$
\text { (a) } \frac{d[O 2]}{d t}=-N_{0} R_{\text {cell }} \exp (\mu t)
$$

The integration of the above equation gives

$$
\text { (b) } \Delta O_{2}=\left[O_{2}\right]_{t i}-\left[O_{2}\right]_{t f}=A(1-\exp (-\mu t))
$$

with

$$
\text { (c) } A=\frac{-N_{0} R_{c e l l}}{\mu}
$$

where $\left[\mathrm{O}_{2}\right]_{t i}$ and $\left[\mathrm{O}_{2}\right]_{t f}$ are the respective $\mathrm{O}_{2}$ concentrations at the starting time point $\left(\mathrm{t}_{i}\right)$ and at the final time point $\left(\mathrm{t}_{f}\right)$. $\Delta \mathrm{O}_{2}=\mathrm{f}(\mathrm{t})$ was fitted to the equation using sigmaplot software to derive $\mu$ and $A=\frac{-N_{0} R_{\text {cell }}}{\mu}$. A was then used to calculate $\mathrm{R}_{\text {cell }}$. Under Fe-limiting conditions, $\Delta \mathrm{O}_{2}$ was small and therefore the equation leads to an approximately linear relationship of $\Delta \mathrm{O}_{2}=\mathrm{N}_{0} \mathrm{R}_{\text {cell }} \mathrm{t}$ where $\mathrm{R}_{\text {cell }}$ is derived from the slope of $\Delta \mathrm{O}_{2}=\mathrm{f}(\mathrm{t})$ measurements. In this case, $\mu=\ln \left(\mathrm{N}_{f}-\mathrm{N}_{0}\right) /\left(\mathrm{N}_{0} \mathrm{t}_{f}\right)$ where $\mathrm{N}_{f}$ is the final cell abundance at $\mathrm{t}_{f}$ derived from flow cytometry. All growth and respiration experiments were conducted in triplicate (where one replicate represents one oxygen sensor vial).

\section{ICL Expression}

Due to the unknown possibility of Fe-contamination resulting from the usage of glass vials, it is not possible to quantitatively calculate the total bioavailable $\mathrm{Fe}$ (Fe') within the medium. Fe-limitation was therefore obtained through the addition of either $0,10,50,100$, and $500 \mu \mathrm{M}$ of DFOB (deferoxamineB) into Aquil medium already containing $5.4 \mu \mathrm{M}$ of Fe. The addition of DFOB was left to equilibrate in the medium for a period of $24 \mathrm{~h}$ prior to its use. Different single carbon sources (acetate, serine and alanine) were added at a final concentration of $100 \mu \mathrm{M}[\mathrm{C}]$ while glucose was added at both $100 \mu \mathrm{M}[\mathrm{C}]$ and $6 \mathrm{mM}[\mathrm{C}]$. The experiments testing different carbon sources or glucose concentrations were conducted using six replicates, while the experiment using different concentrations of DFOB was conducted in triplicate (one replicate representing one $200 \mu \mathrm{L}$ well).

Icl-luc diluted to starting concentrations $\left(1.8 \times \times 10^{5}\right.$ cells $\mathrm{mL}^{-1}$ ) within their respective media and pipetted into $200 \mu \mathrm{L}$ wells of a clear-bottom 96-well microplate (Greiner BioOne) containing $5 \mu \mathrm{L}$ of luciferin (final concentration of $250 \mu \mathrm{M}$ ) and covered with a clear diamond film seal (Thermo Fisher Scientific ${ }^{\mathrm{TM}}$ ). Coinciding with the late-exponential phase, luminescence was measured at $16 \mathrm{~h}$ (5 s per well) using a luminometer (Berthold Centro LB 960). Samples, for the determination of cell abundance by flow cytometry, were taken simultaneously in order to measure expression of $i c l$ per cell. The expression of the $i c l$ was measured as luminescence (arbitrary units, a.u.) normalized to 1000 cell counts.

\section{Statistics}

All statistics were conducted in R-studio (Version 1.0.136). Data was analyzed accordingly using a parametric Analysis of Variance (ANOVA) test after having respectfully met the assumptions of normality and homoscedasticity using a Levene and ShapiroWilk test. A Tukey analysis was subsequently used as a post hoc analysis. In order to account for a skewed and unbalanced dataset obtained for both growth and respiration measurements (i.e., unequal numbers of observations for each level of a factor), data were trimmed and log transformed before conducting a type III ANOVA with contrasts of both factors set to "contr.sum" and "contr.poly" (Wilcox, 2012).

\section{RESULTS}

Icl-luc was grown under Fe-replete conditions $(5.4 \mu \mathrm{M})$ and in the presence of different single carbon sources glucose, acetate, serine and alanine (100 $\mu \mathrm{M}[\mathrm{C}]$, Figure 2) in order to determine the optimal growth conditions while obtaining a low initial $\mathrm{icl}$ expression level due to carbon utilization. Acetate as a single carbon source, served as a control due to its well-established association with the induction of the glyoxylate shunt (Kornberg, 1966). In Fe-replete conditions, the luminescence, as a proxy for icl expression, was especially

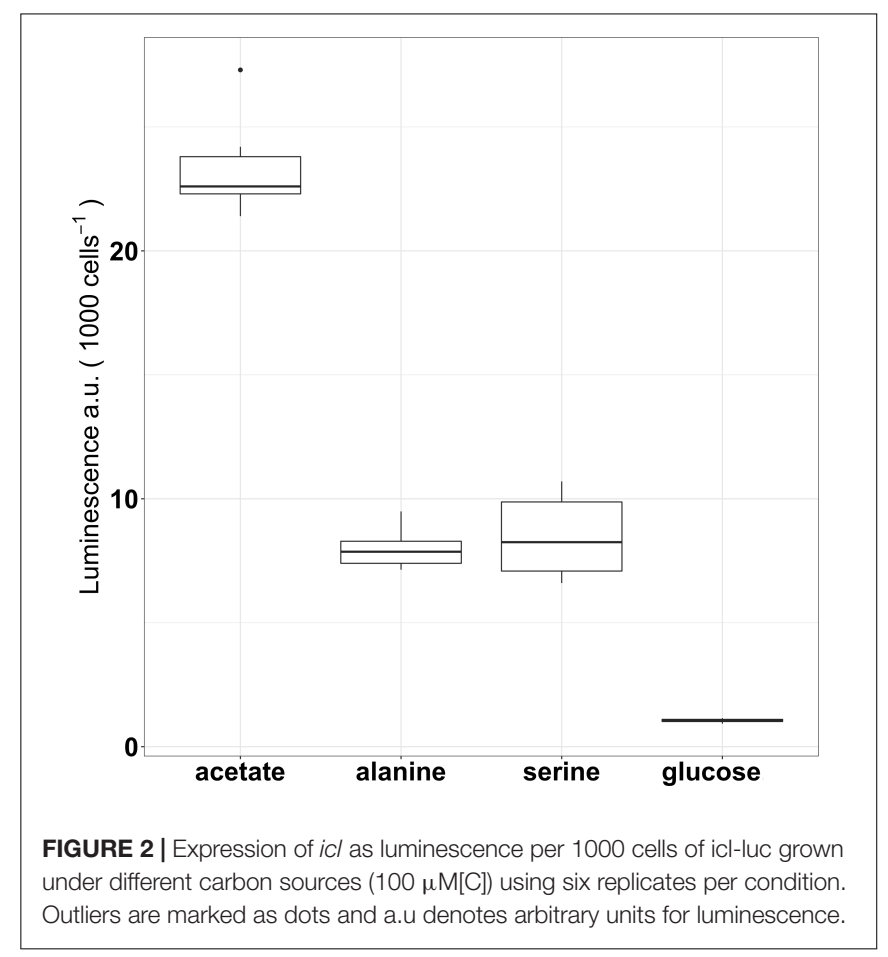


induced when bacteria were grown in acetate with a luminescence of 23.4 a.u cell ${ }^{-1}$ and a standard error of \pm 0.9 , while an intermediary level of expression was observed when icl-luc was grown in either serine $\left(8.5 \pm 0.7\right.$ a.u cell $\left.{ }^{-1}\right)$ or alanine $\left(8.0 \pm 0.4\right.$ a.u cell $\left.{ }^{-1}\right)$, two amino acids. Luminescence was lowest in glucose, where almost no expression $(1.1 \pm 0.1$ a.u cell ${ }^{-1}$ ) was detected. An ANOVA and subsequent Tukey Test confirmed that luminescence was significantly different between all carbon sources $(p<0.0005)$, except between alanine and serine $(p=0.937)$. The above results led us to confirm the use of glucose for the acclimation of our bacterial strains while consequently subjecting them to Felimitation.

Luminescence was further compared between two different glucose concentrations under Fe-replete conditions (5.4 $\mu \mathrm{M}$, Figure 3 ) in order to determine whether the carbon concentration can also induce the glyoxylate shunt. Luminescence remained low $\left(2.3 \pm 0.1\right.$ a.u cell $\left.{ }^{-1}\right)$ when cells were grown in $60 \times$ more carbon $(6 \mathrm{mM}[\mathrm{C}])$ despite the signal being twofold higher compared to cells grown in $100 \mu \mathrm{M}[\mathrm{C}]$ $(p<0.0005)$. A concentration of $6 \mathrm{mM}[\mathrm{C}]$ was chosen for our acclimation conditions as it provided the best conditions for

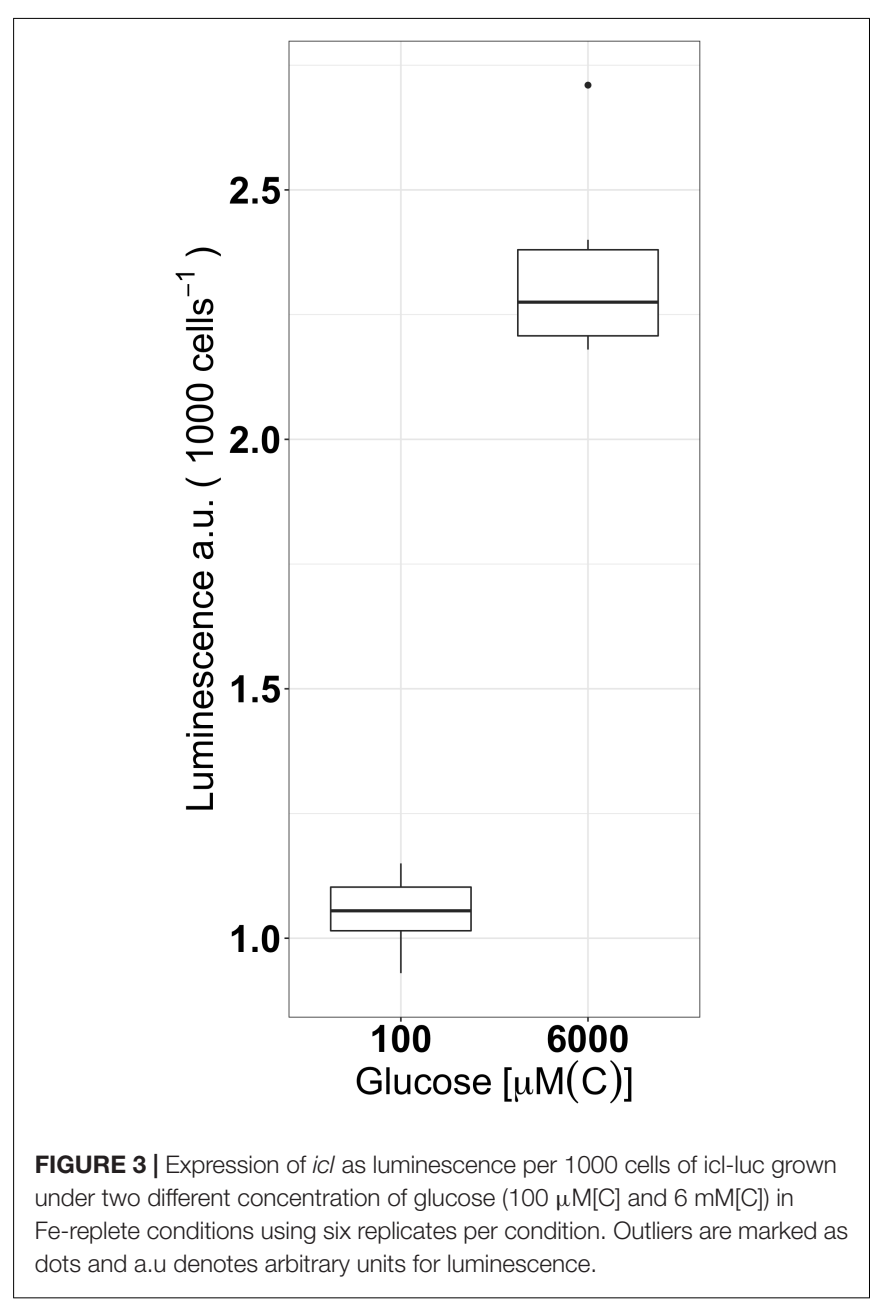

growth while maintaining the lowest induction of the glyoxylate shunt as a direct result of carbon source utilization.

Icl-luc was subsequently grown under different levels of Fe-limitation through the addition of DFOB, a strong $\mathrm{Fe}$ chelator which decreases Fe' from the medium, using different final concentrations $(0,10,50,100$, and $500 \mu \mathrm{M})$. As seen in previous experiments, in glucose and under Fe-replete conditions, luminescence was low $\left(3.6 \pm 0.5\right.$ a.u cell $\left.{ }^{-1}\right)$ and quickly increased to $14.6 \pm 1.4$ a.u cell ${ }^{-1}$ with the addition of $10 \mu \mathrm{M}$ DFOB. Luminescence peaked around $100 \mu \mathrm{M}$ DFOB $\left(27 \pm 3.1\right.$ a.u cell $\left.{ }^{-1}\right)$ and slightly decreased with the addition of $500 \mu \mathrm{M}$ DFOB $\left(22.7 \pm 2.6\right.$ a.u cell $\left.{ }^{-1}\right)$. Due to a skewed distribution of the data set, a natural $\log (\ln )$ transformation was conducted in order to, respectively, meet the assumptions of normality and homogeneity of variance required by an ANOVA test (Figure 4). A post hoc Tukey analysis revealed significant differences in icl expression between Fe-replete and gradually increasing levels of Fe-limitation ( $p<0.0005)$. No significant differences in $i c l$ expression were found between the high levels of Fe-limitation (addition of 50, 100, and $500 \mu \mathrm{M}$ final concentrations of DFOB).

Both growth and respiration rates were derived from $\mathrm{O}_{2}$ measurements over time for the wt and the $\Delta \mathrm{icl}$ grown under different levels of Fe-limitation (0, 10, and $100 \mu \mathrm{M}$ DFOB) in $6 \mathrm{mM}[\mathrm{C}]$ glucose (Figures 5, 6). For the statistical analysis of our data, growth rates were $\ln$ transformed in order to account for the skewed data set and to meet the assumptions of an ANOVA test. In Fe-replete conditions, growth rates were roughly the same between the wt $\left(10.4 \pm 0.4 \mathrm{~d}^{-1}\right)$ and $\Delta \mathrm{icl}$ $\left(9.8 \pm 0.9 \mathrm{~d}^{-1}\right)$ and a Tukey test confirmed them to be statistically

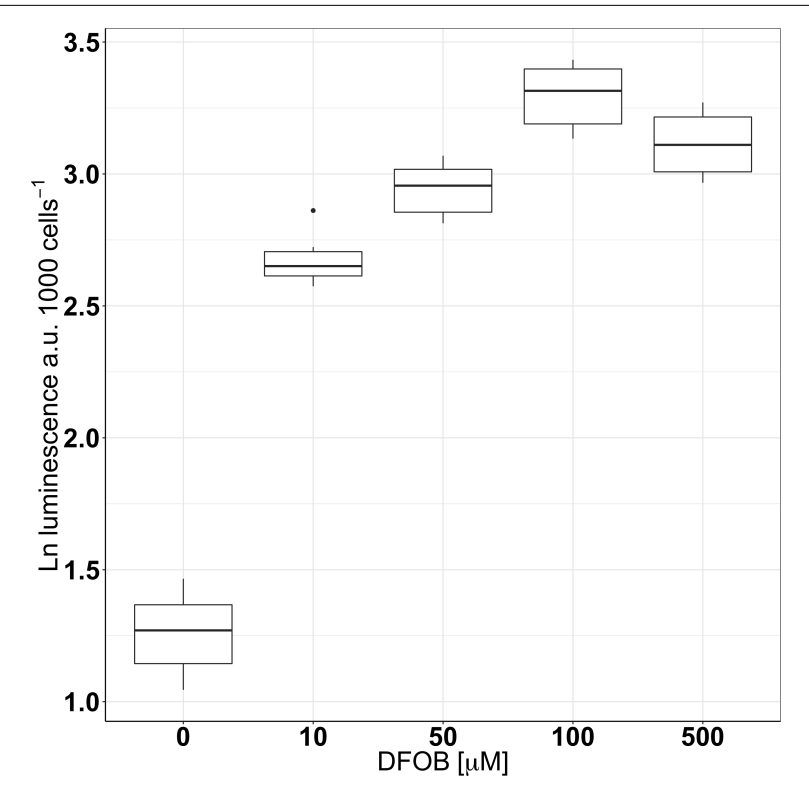

FIGURE 4 | The natural logarithm (In) of icl-expression measured as luminescence per 1000 cells of icl-luc grown in $6 \mathrm{mM}[\mathrm{C}]$ glucose under different levels of Fe-limitation through the addition of DFOB performed in triplicate. Outliers are marked as dots and a.u denotes arbitrary units for luminescence. 


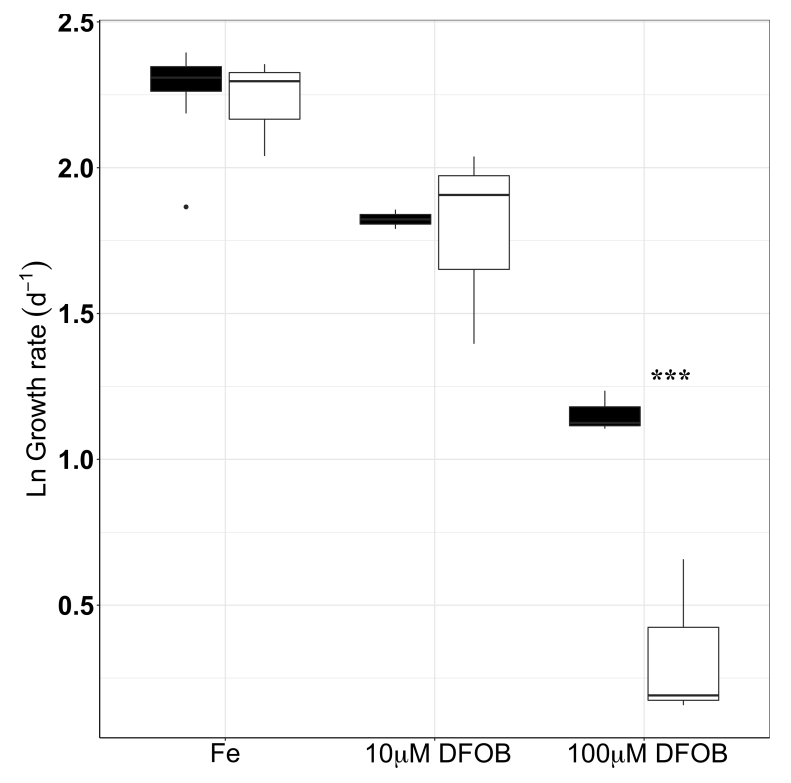

FIGURE 5 | Growth rates of wt (black) and $\Delta \mathrm{icl}$ (white) under different levels of Fe-limitation (Fe-replete, $10 \mu \mathrm{M}$ DFOB, $100 \mu \mathrm{M}$ DFOB) performed in triplicate. The natural logarithm (In) was used in order to account for a skewed data set. Black dots represent outliers while significant differences between wt and $\Delta \mathrm{icl}$ are marked with an asterisk, where ${ }^{*} p<0.05,{ }^{* *} p<0.005,{ }^{* * *} p<0.0005$.

insignificant $(p=0.9998)$. A clear decrease in growth rate was observed with increasing Fe-limitation for both the wt and the $\Delta$ icl (Figure 5). However, under extreme Fe-limitation (100 $\mu \mathrm{M}$ DFOB), an $85 \%$ reduction in the growth rate was seen for $\Delta \mathrm{icl}$ $\left(1.4 \pm 0.4 \mathrm{~d}^{-1}\right)$ while only a $70 \%$ reduction was observed for wt $\left(3.2 \pm 0.2 \mathrm{~d}^{-1}\right)$. A Tukey test confirmed this difference as significant $(p<0.0005)$. The respiration rate, like the growth rate, decreased with increasing Fe-limitation for both the $\Delta \mathrm{icl}$ and the wt (Figure 6). In replete conditions, a higher respiration rate was observed in $\Delta \mathrm{icl}\left(4.4 \pm 0.4 \mathrm{fmol} \mathrm{h}^{-1}\right.$ cell $\left.^{-1}\right)$ compared to the wt $\left(3.2 \pm 0.3 \mathrm{fmol} \mathrm{h}^{-1}\right.$ cell $\left.^{-1}\right)$ although this was not significantly different $(p=0.2109)$. Under Fe-limitation, the respiration rate decreased to around $1.4 \pm 0.3 \mathrm{fmol} \mathrm{h}^{-1}$ cell $^{-1}$ for the wt and was even lower for $\Delta \mathrm{icl}\left(0.9 \pm 0.1 \mathrm{fmol} \mathrm{h}^{-1}\right.$ cell $\left.^{-1}\right)$. A Tukey test further revealed that the respiration rate of the wt was significantly higher than the respiration rate of $\Delta \mathrm{icl}$ $(p=0.012)$ under extremely low Fe-levels (100 $\mu$ M DFOB), while no differences were found under intermediate Fe-levels $(10 \mu \mathrm{M}$ DFOB, $p=0.9038$ ).

To confirm the role of icl in the glyoxylate shunt under Fe-limitation, the gene was constitutively expressed in trans in the form of a plasmid (icl+, Table 1). $\mathrm{O}_{2}$ measurements were obtained from wt, $\Delta \mathrm{icl}$ and icl+ grown under strong $\mathrm{Fe}$ limitation and conducted using eight replicates (100 $\mu$ M DFOB; Supplementary Figure 2). For this experiment, the wt expressed a growth rate of $5.21 \pm 0.04 \mathrm{~d}^{-1}$ and a respiration rate of $0.81 \pm 0.02 \mathrm{fmol} \mathrm{O}_{2} \mathrm{~h}^{-1}$ cell $^{-1}$. The removal of the glyoxylate shunt $(\Delta \mathrm{icl})$ caused a significant overall decrease of $\pm 30 \%$ in both the growth and respiration rates $(p<0.0005)$. The growth

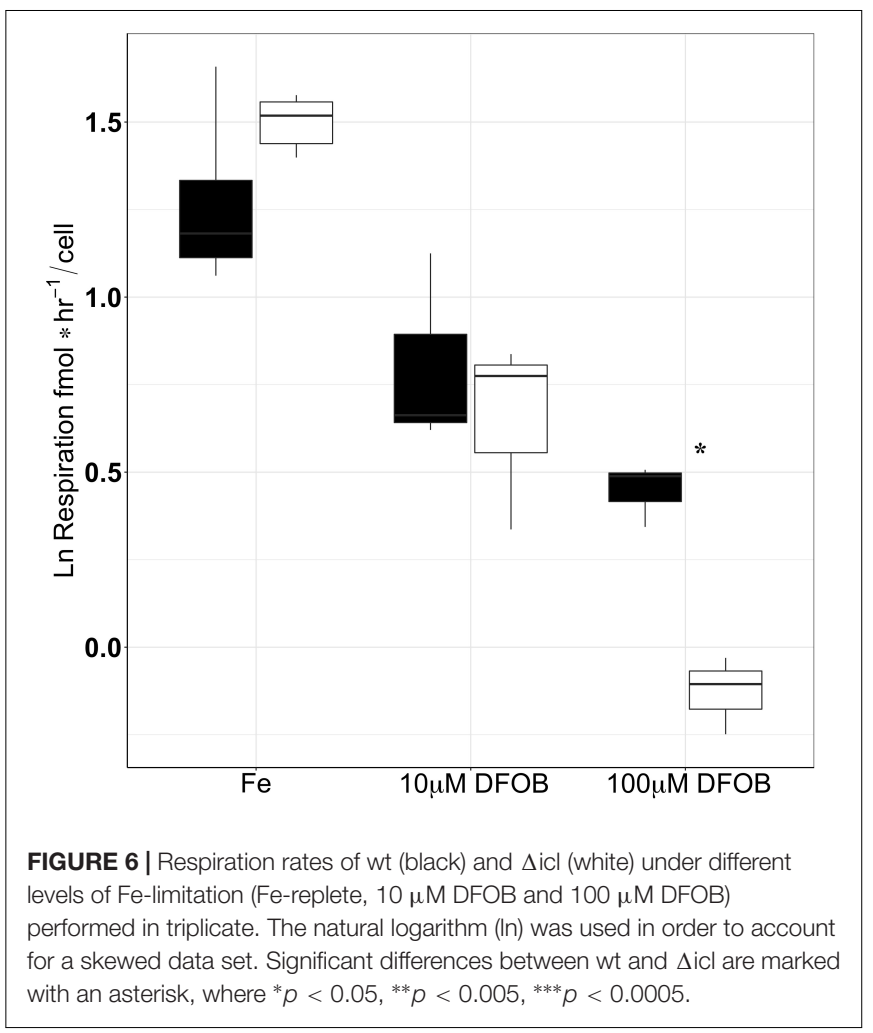

TABLE 1 | Growth and respiration rates obtained from $\Delta \mathrm{O}_{2}$ measurements derived from eight replicates of $P$. angustum $\mathrm{S} 14$ (wt), $\Delta \mathrm{icl}$ and the complement icl+ when grown in Fe-replete conditions containing $100 \mu \mathrm{M}$ DFOB.

\begin{tabular}{lll}
\hline Bacterial strain & Growth rate $\left(\right.$ day $\left.^{-\mathbf{1}}\right)$ & $\begin{array}{l}\text { Respiration rate } \\
\text { (fmol hr }\end{array}$ \\
\hline P. angustum S14 (wt) & $5.21 \pm 0.04$ & $0.81 \pm 0.02$ \\
$\Delta \mathrm{icl}$ & $2.91 \pm 0.04$ & $0.42 \pm 0.01$ \\
$\mathrm{icl}+$ & $5.95 \pm 0.03$ & $0.85 \pm 0.02$ \\
\hline
\end{tabular}

rate was reduced to around $2.9 \pm 0.04 \mathrm{~d}^{-1}$, while the respiration rate decreased to $0.4 \pm 0.01 \mathrm{fmol} \mathrm{O}_{2} \mathrm{~h}^{-1}$ cell $^{-1}$. A complete restoration of both the growth $\left(5.95 \pm 0.03 \mathrm{~d}^{-1}\right)$ and respiration rate $\left(0.85 \pm 0.02 \mathrm{fmol} \mathrm{O}_{2} \mathrm{~h}^{-1}\right.$ cell) occurred when the gene was provided in trans $(\mathrm{icl}+)$. The growth rate was slightly higher for $\mathrm{icl}+\left(5.95 \pm 0.03 \mathrm{~d}^{-1}\right)$ compared to the wt $\left(5.21 \pm 0.03 \mathrm{~d}^{-1}\right)$ but was not considered to be significantly different (Tukey test, $p=0.334)$.

\section{DISCUSSION}

In general, an overall decrease in the growth rate is observed when marine heterotrophic bacteria are subjected to $\mathrm{Fe}$ limitation. The magnitude of this decrease, however, depends on the degree of Fe-limitation and is strain specific as certain bacterial species were even reported to have higher growth rates under Fe-limitation than under replete conditions (Tortell et al., 1996; Granger and Price, 1999; Fourquez et al., 2014; Table 2). Within our model organism P. angustum S14, we 
TABLE 2 | Results of previous publications including this publication depicting growth rates (per day) of marine heterotrophic bacteria grown in Aquil and in either Fe-replete or Fe-limiting conditions.

\begin{tabular}{|c|c|c|c|c|c|}
\hline Bacterial strain & Isolate & Fe-replete: growth $\left(\mathrm{d}^{-1}\right)$ & Fe-limited: growth $\left(\mathrm{d}^{-1}\right)$ & Carbon source & Publication \\
\hline Photobacterium angustum & S14 & $9.4 \mathrm{a}$ & $6.2 b, 3.2 c$ & Glucose (6 mM[C]) & This publication \\
\hline Alteromonas macleodii & Jul88 & $8 d$ & $4 e$ & Mixed* & Tortell et al., 1996 \\
\hline $\mathrm{n} / \mathrm{a}$ & LMb1 & $6.5 d$ & $3.8 \mathrm{e}$ & - & - \\
\hline$n / a$ & Puh3a & $10 d$ & $4 \mathrm{e}$ & - & - \\
\hline$n / a$ & Tef2 & $6 d$ & $10 e$ & - & - \\
\hline Pseudoalteromonas rubra & Lmg1 & $7.8 d$ & $10 e$ & - & - \\
\hline Pseudoalteromonas haloplanktis & Neptune & $12.9 f$ & $6.74 \mathrm{~g}$ & Mixed* & Granger et al., 1999 \\
\hline $\mathrm{n} / \mathrm{a}$ & P20pac & $4.27 f$ & $1.21 \mathrm{~g}$ & - & - \\
\hline Pseudomonas sp. & Iso15 & $3.59 f$ & $3.77 \mathrm{~g}$ & - & - \\
\hline Alteromonas macleodii & Jul88 & $7.37 f$ & $2.18 \mathrm{~g}$ & - & - \\
\hline Pseudoalteromonas rubra & Lmg1 & $15.7 f$ & $9.95 \mathrm{~g}$ & - & - \\
\hline Pseudoalteromonas piscicida & PWF3 & $11.9 f$ & $5.9 \mathrm{~g}$ & - & - \\
\hline Vibrio natriegens & PWHЗа & $20.9 f$ & $5.55 \mathrm{~g}$ & - & - \\
\hline Alteromonas macleodii & MOLA377 & $11.5 \mathrm{~h}$ & $9.6 i$ & Mixed* & Fourquez et al., 2014 \\
\hline Alteromonas macleodii & MOLA60 & $12.2 \mathrm{~h}$ & $6.1 \mathrm{i}$ & - & - \\
\hline
\end{tabular}

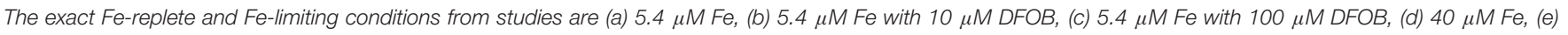
$25 \mu \mathrm{M} \mathrm{Fe}$, (f) $8.4 \mu \mathrm{M} \mathrm{Fe}$, (g) $12.5 \mathrm{nM} \mathrm{Fe,} \mathrm{(h)} 5.4 \mu \mathrm{M} \mathrm{Fe}$, and (i) $5.4 \mathrm{nM} \mathrm{Fe}$. The asteriks (*) stands for a mixed carbon source of bactopeptone and casein.

observed that, under extreme limitation (DFOB $100 \mu \mathrm{M}$ ), the growth rate can decrease to as low as $70 \%$ for the wt and $85 \%$ for $\Delta \mathrm{icl}$ in comparison to their respective growth rate under Fe-replete conditions. This decrease in growth rate could be correlated to a decrease in intracellular Fe-concentrations and thus the Fe-quota of the cell (Hubbard et al., 1986; Kaplan et al., 2006; Fourquez et al., 2014). As over $90 \%$ of intracellular $\mathrm{Fe}$ is predicted to reside within the enzymes of the electron-transport chain within marine heterotrophic bacteria, the reduction of a cell's Fe-quota due to Fe-deficiency can directly be linked to a decline in ATP production as well as a cell's respiration rate (Tortell et al., 1996; Kirchman et al., 2003).

The decline in respiration rate, as observed in $P$. angustum S14 and other strains (Hubbard et al., 1986; Oexle et al., 1999; Fourquez et al., 2014) subjected to Fe-limitation, is commonly derived from oxygen consumption measurements. However, due to different culturing and trace metal conditions further comparisons between the respiration rates prove difficult. Comparable conditions were, however, used in the study of Fourquez et al. (2014). Although P. angustum S14 had similar growth rates as those observed in both strains of A. macleodii under the same Fe-replete conditions (see Table 2), the respiration rate of $P$. angustum S14 was lower and more similar to the respiration rate of $A$. macleodii under Fe-limiting conditions. This is likely due to variations amongst bacterial strains and differences in both the carbon source(s) and concentrations that were utilized in each experiment.

Although decreased growth and respiration rates under $\mathrm{Fe}$ limitation are the result of an overall lower metabolism and inefficient electron transport chain, certain heterotrophic bacteria may have the potential to remodel their metabolism in order to minimize dependency on Fe-containing enzymes and pathways (Oexle et al., 1999; Kaplan et al., 2006; Fourquez et al., 2014).
In theory, there are two strategies by which a bacterium can rearrange its metabolism in order to cope with Fe-stress (Caza and Kronstad, 2013). First, it can increase its effort in the production of Fe-uptake molecules such as siderophores or in the number and diversity of Fe-transporter enzymes (Sigel and Payne, 1982; Tortell et al., 1999; Kim et al., 2003; Wiens et al., 2014; Sasnow et al., 2016). Secondly, a bacterium can reduce its Fe-quota by decreasing its dependency on Fecontaining enzymes. For example, within the TCA cycle, E. coli can exchange the Fe-dependent fumarase $\mathrm{A} / \mathrm{B}$ with the $\mathrm{Fe}$ independent fumarase C (Park and Gunsalus, 1995), a strategy that has also been shown for A. macleodii (Fourquez et al., 2014). Another example is the redirection of ATP production from the classic phosphorylation oxidative respiratory chain towards the less Fe-dependent pathway of glycolysis (Oexle et al., 1999; Fourquez et al., 2014; Thimm et al., 2017). The results from the present study show that the induction of the glyoxylate shunt is undertaken in $P$. angustum $\mathrm{S} 14$ as a result of $\mathrm{Fe}$ limitation.

Serving as an alternative pathway within the classic TCA cycle, the glyoxylate shunt allows for the conservation of carbon atoms that would otherwise have been utilized for the production of $\mathrm{CO}_{2}$. The glyoxylate shunt is frequently associated with its role in the metabolism of two-carbon substrates, such as acetate, and the replenishment of TCA cycle intermediates essential for the production of biomolecules (Vanni et al., 1990; Schwalbach et al., 2010; Carini et al., 2012). Its upregulation under Fe-limitation has previously been reported in culture work using comparative proteomics or transcriptomics (Smith et al., 2010; Fourquez et al., 2014). Observations made in the Southern Ocean further illustrated that the expression of $i c l$ in the SAR11 clade varied with contrasting Fe-regimes (Beier et al., 2015). Our experimental setup using a bioreporter for the expression of icl agreed with earlier studies showing an upregulation of the glyoxylate 
shunt under Fe-limitation. Furthermore, field studies could not verify whether the expression of the glyoxylate shunt was a direct effect of Fe-limitation or an indirect effect of the quantity and quality of organic matter provided by phytoplankton (Kirchman et al., 2000; Obernosterer et al., 2015). As shown in our study, using acetate, serine, alanine or glucose as sole growth substrate, differences in the carbon sources also play an important role in the upregulation of icl (Wolfe, 2005; Blank et al., 2008; Sudarsan et al., 2014).

Comparison experiments between the wildtype, the gene knockout mutant $(\Delta \mathrm{icl})$ as well as its complement strain $(\mathrm{icl}+)$ verified that the induction of the glyoxylate shunt can indeed be utilized as a strategy to improve cell growth and respiration rates under strong Fe-limitation for P. angustum S14. Previous work had already observed that the glyoxylate shunt appears to be associated with various adaptive strategies against conditions resulting in an inefficient electron transport chain. For example, under $\mathrm{O}_{2}$-limitation, Mycobacterium tuberculosis strains were shown to induce the glyoxylate shunt and replenish $\mathrm{NAD}+$ which can be utilized for ATP production through glycolysis (Wayne and Lin, 1982; Wayne and Sohaskey, 2001; Eoh and Rhee, 2013). Its upregulation was also observed in $P$. aeruginosa strains harboring resistance to antibiotics targeting the electron transport chain (Meylan et al., 2017). Although the effect of Fe-limitation extends further than an inefficient electron transport chain due to the involvement of $\mathrm{Fe}$ as a co-factor within various other enzymes, various studies have provided concrete examples as to how the induction of the glyoxylate shunt might aid a cell subjected to the effects of Fe-limitation. Importantly, the link between the glyoxylate shunt and Fe-limitation was also observed in $P$. aeruginosa with regards to oxidative stress ( $\mathrm{Ha}$ et al., 2018). In fact, several other studies have linked the glyoxylate shunt with oxidative stress (Ahn et al., 2016; Meylan et al., 2017). Oxidative respiration, by means of the electron transport chain, is inevitably linked to the formation of reactive oxygen species (ROS; Cadenas, 1989; Fridovich, 1998; Lesser, 2006). The production of ROS can be neutralized by Fe-containing enzymes such as ferrous superoxide dismutase and peroxidase/catalases, which are, respectively, used to convert ROS molecules to $\mathrm{H}_{2} \mathrm{O}_{2}$ which in turn is converted to the non-reactive molecules of $\mathrm{H}_{2} \mathrm{O}$ and $\mathrm{O}_{2}$ (Tiwari et al., 2002). Studies have also shown that the disruption or an increased inefficiency of the electron transport chain by, for example, Fe-limitation can increase the susceptibility of certain bacteria, but not all, to oxidative stress and the accumulation of ROS and $\mathrm{H}_{2} \mathrm{O}_{2}$ within the cell (Baichoo et al., 2002; Latifi et al., 2005; Figueira et al., 2013; Leaden et al., 2018). It is important to note, however, that $P$. angustum S14 in particular is known for its efficient resistance to high levels of $\mathrm{H}_{2} \mathrm{O}_{2}$ (Ostrowski et al., 2001; Vattanaviboon and Mongkolsuk, 2001; Schott et al., 2003) which is in part due to several oxidative response enzymes including glyoxalase, AhpC, recA as well as ferrous superoxide dismutase and peroxidase (Matallana-Surget et al., 2012, 2013).
Under Fe-limitation, the induction of the glyoxylate shunt itself does not have the direct capability of replacing the loss of ATP. Instead, the glyoxylate shunt seems to serve as a pathway that redirects a cell's metabolism away from the electron transport chain through the conservation of carbon while preventing both the unnecessary production of NADH and lowering the possibility of a cell to encounter oxidative stress due to an inefficient electron transport chain. This could explain why, although, the growth and respiration rates of the wt improved in comparison to $\Delta \mathrm{icl}$ under strong Fe-limitation, these rates still remained significantly lower than those found under Fe-replete conditions. Furthermore, the induction of the glyoxylate shunt is also known to occur as the enzyme ICL competes with the metabolic enzyme isocitrate dehydrogenase $(I D H)$ for the substrate isocitrate (Holms and Bennett, 1971). Compared to ICL, IDH has a higher affinity for isocitrate and the induction of the glyoxylate shunt can thus only be maintained after a build-up of isocitrate with concentration above that of $0.6 \mathrm{mM}$ (El-Mansi et al., 1985). Under Fe-limitation, the downregulation of IDH (Domínguez-Martín et al., 2014; Fourquez et al., 2014; Ha et al., 2018) could form a sufficient build-up of isocitrate which is then redirected towards the glyoxylate shunt.

Interestingly, the proteorhodopsin-containing Dokdonia sp. MED134 was also shown to induce the glyoxylate shunt upon the presence of light (Palovaara et al., 2014). Proteorhodopsin, a light-driven proton pump can be linked towards ATP synthesis whilst redirecting the TCA cycle towards the glyoxylate shunt in order to increase biosynthesis. It is known that P. angustum S14 contains a proteorhodopsin gene. Whether, in the presence of light, the combined use of the glyoxylate shunt and proteorhodopsin in $P$. angustum S14 serves as an additional strategy in coping with Fe-limitation would deserve further investigation.

Lastly, under strong Fe-limitation, a lower respiration rate was observed in bacterial strains without the ability to induce the glyoxylate shunt $(\Delta \mathrm{icl})$. A similar observation was made for a coastal strain of A. macleodii (Fourquez et al., 2014). Under Felimitation, the coastal strain overexpressed $i c l$ and had a higher respiration rate in comparison to the oceanic strain which did not induce the glyoxylate shunt. In another study, the inhibition of the electron transport chain by antibiotics (and not $\mathrm{Fe}$ limitation), induced the glyoxylate shunt but was not associated with a decreased respiration rate (Meylan et al., 2017). Indeed, when considering the link between the activity of the glyoxylate shunt and the respiration rate, succinate dehydrogenase (SDH), an Fe-S enzyme that is required in both the TCA cycle and the electron transport chain (Rutter et al., 2010), may play a central role (Figure 1). Under strong Fe-limitation, the flow of electrons resulting from the entire TCA cycle through the reduction of $\mathrm{NADH}$ and $\mathrm{FADH}_{2}$, is principally reduced by the decline of activity in complex I which contains seven Fe-S clusters. Although the induction of the glyoxylate shunt further reduces the production of $\mathrm{NADH}$, our results also suggest that this is largely compensated by an enhanced electron flow provided by an increase in SDH activity supplied by isocitrate lyase. It is thus 
possible, that the induction of the glyoxylate shunt under Felimitation, helps rearrange bacterial metabolism in a way which increases the efficiency and ultimately the oxygen consumption rate within the cell.

Our results with a model marine heterotrophic bacterium lead to a better understanding of bacteria and their ability to acclimate under strong Fe-limitation. For P. angustum S14, Fe-limitation significantly inhibits both growth and respiration rates. However, the impact of Fe-limitation is countered by the induction of the glyoxylate shunt and its absence led to a further 30\% decline in both growth and respiration rates within our model organism. The glyoxylate shunt is widely distributed amongst aerobic marine bacteria (Palovaara et al., 2014; Ahn et al., 2016) including SAR11 (Smith et al., 2010; Beier et al., 2015). Ultimately, this form of plasticity can have consequences for biogeochemical cycling as bacteria with a glyoxylate shunt tend to have a more efficient metabolism when subjected to Fe-limitation as compared to a bacterial strain that does not.

\section{DATA AVAILABILITY}

The raw data, plots and data-analysis supporting the conclusions of this manuscript has been made available through the following link https://github.com/cocokoedooder/Stats_ICLP.angS14.

\section{AUTHOR CONTRIBUTIONS}

SB and IO conceived the study. F-YB oversaw the creation of the knockout mutant and bioreporter of $P$. angustum

\section{REFERENCES}

Ahn, S., Jung, J., Jang, I., Madsen, E. L., and Park, W. (2016). Role of glyoxylate shunt in oxidative stress response. J. Biol. Chem. 291, 11928-11938. doi: 10. 1074/jbc.M115.708149

Alberts, B., Johnson, A., Lewis, J., Raff, M., Roberts, K., and Walter, P. (eds). (2002). "Electron transport chains and their proton pumps," in Molecular Biology of the Cell, 4th Edn, (New York, NY: Garland Science), 1-10.

Almaas, E., Oltvai, Z. N., and Barabási, A.-L. (2005). The activity reaction core and plasticity of metabolic networks. PLoS Comput. Biol. 1:e68. doi: 10.1371/journal. pcbi.0010068

Andrews, S. C., Robinson, A. K., and Rodríguez-Quiñones, F. (2003). Bacterial iron homeostasis. FEMS Microbiol. Rev. 27, 215-237. doi: 10.1016/S0168-6445(03) 00055-X

Azam, F., Field, J. G., Graf, J. S., Meyer-Rei, L. A., and Thingstad, F. (1983). The ecological role of water-column microbes in the sea*. Ecol. Prog. Ser. Mar. 10, 257-263. doi: 10.3354/meps010257

Baichoo, N., Wang, T., Ye, R., and Helmann, J. D. (2002). Global analysis of the Bacillus subtilis Fur regulon and the iron starvation stimulon. Mol. Microbiol. 45, 1613-1629. doi: 10.1046/j.1365-2958.2002.03113.x

Beier, S., Gálvez, M. J., Molina, V., Sarthou, G., Quéroué, F., Blain, S., et al. (2015). The transcriptional regulation of the glyoxylate cycle in SAR11 in response to iron fertilization in the Southern Ocean. Environ. Microbiol. Rep. 7, 427-434. doi: 10.1111/1758-2229.12267

Bertani, G. (1951). Studies on lysogenesis. I. The mode of phage liberation by lysogenic Escherichia coli. J. Bacteriol. 62, 293-300.

Blank, L. M., Ionidis, G., Ebert, B. E., Bühler, B., and Schmid, A. (2008). Metabolic response of Pseudomonas putida during redox biocatalysis in the presence of a second octanol phase. FEBS J. 275, 5173-5190. doi: 10.1111/j.1742-4658.2008. 06648.x
S14 which were conducted by RVG and VV. AG conducted cultures and the oxygen (respiration and growth) and expression experiments. YL and CK created the complement. CK was further responsible for the statistical analysis, performing the complementation experiments, and writing the manuscript. IO and $\mathrm{SB}$ provided the feedback and guidance during the writing. All authors discussed the results and contributed to the final manuscript.

\section{FUNDING}

This work was financially supported in part by a grant from the French National Research Agency (ANR-16-CE32-0008-01) and the National Centre for Marine Biological Resources (EMBRCFrance).

\section{ACKNOWLEDGMENTS}

The authors would like to thank Maxime Bruto and Eric Schmidt for consultation on the statistical and data analysis of the work.

\section{SUPPLEMENTARY MATERIAL}

The Supplementary Material for this article can be found online at: https://www.frontiersin.org/articles/10.3389/fmars. 2018.00435/full\#supplementary-material

Cadenas, E. (1989). Biochemistry of oxygen toxicity. Annu. Rev. Biochem. 58, 79-110. doi: 10.1146/annurev.bi.58.070189.000455

Carini, P., Steindler, L., Beszteri, S., and Giovannoni, S. J. (2012). Nutrient requirements for growth of the extreme oligotroph Candidatus Pelagibacter ubique HTCC1062 on a defined medium. ISME J. 7, 592-602. doi: 10.1038/ ismej.2012.122

Caza, M., and Kronstad, J. W. (2013). Shared and distinct mechanisms of iron acquisition by bacterial and fungal pathogens of humans. Front. Cell. Infect. Microbiol. 3:80. doi: 10.3389/fcimb.2013.00080

Davey, E. W., Gentile, J. H., Erickson, S. J., and Betzer, P. (1970). Removal of trace metals from marine cluster media. Limnol. Oceanogr. 15, 486-488. doi: 10.4319/lo.1970.15.3.0486

Domínguez-Martín, M. A., López-Lozano, A., Diez, J., Gómez-Baena, G., RangelZúñiga, O. A., and García-Fernández, J. M. (2014). Physiological regulation of isocitrate dehydrogenase and the role of 2-oxoglutarate in Prochlorococcus sp. Strain PCC 9511. PLoS One 9:e103380. doi: 10.1371/journal.pone.01 03380

Ducklow, H. W., Steinberg, D. K., and Buesseler, K. O. (2001). Upper ocean carbon export and the biological pump. Oceanography 14, 50-58. doi: 10.5670/oceanog. 2001.06

El-Mansi, E. M. T., Nimmo, H. G., and Holms, W. H. (1985). The role of isocitrate in control of the phosphorylation of isocitrate dehydrogenase in Escherichia coli ML308. FEBS Lett. 183, 251-255. doi: 10.1016/0014-5793(85)80787-0

Eoh, H., and Rhee, K. Y. (2013). Multifunctional essentiality of succinate metabolism in adaptation to hypoxia in Mycobacterium tuberculosis. Proc. Natl. Acad. Sci. U.S.A. 110, 6554-6559. doi: 10.1073/pnas.1219375110

Figueira, T. R., Barros, M. H., Camargo, A. A., Castilho, R. F., Ferreira, J. C. B., Kowaltowski, A. J., et al. (2013). Mitochondria as a source of reactive oxygen and nitrogen species: from molecular mechanisms to human health. Antioxid. Redox Signal. 18, 2029-2074. doi: 10.1089/ars.2012.4729 
Fourquez, M., Devez, A., Schaumann, A., Guéneuguès, A., Jouenne, T., Obernosterer, I., et al. (2014). Effects of iron limitation on growth and carbon metabolism in oceanic and coastal heterotrophic bacteria. Limnol. Oceanogr. 59, 349-360. doi: 10.4319/lo.2014.59.2.0349

Fridovich, I. (1998). Oxygen toxicity: a radical explanation. J. Exp. Biol. 201, 1203-1209.

Garcia, H. E., and Gordon, L. I. (1992). Oxygen solubility in seawater: better fitting equations. Limnol. Oceanogr. 37, 1307-1312. doi: 10.4319/lo.1992.37.6.1307

Granger, J., and Price, N. M. (1999). The importance of siderophores in iron nutrition of heterotrophic marine bacteria. Limnol. Oceanogr. 44, 541-555. doi: 10.4319/lo.1999.44.3.0541

Ha, S., Shin, B., and Park, W. (2018). Lack of glyoxylate shunt dysregulates iron homeostasis in pseudomonas aeruginosa. Microbiology 164, 587-599. doi: 10. 1099/mic.0.000623

Holms, H. (1996). Flux analysis and control of the central metabolic pathways in Escherichia coli. FEMS Microbiol. Rev. 19, 85-116. doi: 10.1111/j.1574-6976. 1996.tb00255.x

Holms, W. H., and Bennett, P. M. (1971). Regulation of isocitrate dehydrogenase activity in Escherichia coli on adaptation to acetate. J. Gen. Microbiol. 65, 57-68. doi: 10.1099/00221287-65-1-57

Hubbard, J. A. M., Lewandowska, K. B., Hughes, M. N., and Poole, R. K. (1986). Effects of iron-limitation of Escherichia coli on growth, the respiratory chains and gallium uptake. Arch. Microbiol. 146, 80-86. doi: 10.1007/BF00690163

Humphrey, B., Kjelleberg, S., and Marshall, K. C. (1983). Responses of marine bacteria under starvation conditions at a solid-water interface. Appl. Environ. Microbiol. 45, 43-47.

Kaplan, J., McVey Ward, D., Crisp, R. J., and Philpott, C. C. (2006). Iron-dependent metabolic remodeling in S. cerevisiae. Biochim. Biophys. Acta 1763, 646-651. doi: 10.1016/j.bbamcr.2006.03.008

Kim, E.-J., Sabra, W., and Zeng, A.-P. (2003). Iron deficiency leads to inhibition of oxygen transfer and enhanced formation of virulence factors in cultures of Pseudomonas aeruginosa PAO1. Microbiology 149, 2627-2634. doi: 10.1099/ mic. $0.26276-0$

Kirchman, D. L., Hoffman, K. A., Weaver, R., and Hutchins, D. A. (2003). Regulation of growth and energetics of a marine bacterium by nitrogen source and iron availability. Mar. Ecol. Prog. Ser. 250, 291-296. doi: 10.3354/ meps 250291

Kirchman, D. L., Meon, B., Cottrell, M. T., Hutchins, D. A., Weeks, D., and Bruland, K. W. (2000). Carbon versus iron limitation of bacterial growth in the California upwelling regime. Limnol. Oceanogr. 45, 1681-1688. doi: 10.4319/lo. 2000.45.8.1681

Knowles, J. R. (1980). Enzyme-catalyzed phosphoryl transfer reactions. Annu. Rev. Biochem. 49, 877-919. doi: 10.1146/annurev.bi.49.070180.004305

Kornberg, H. L. (1966). The role and control of the glyoxylate cycle in Escherichia coli. Biochem. J. 99, 1-11. doi: 10.1042/bj0990001

Kornberg, H. L., and Krebs, H. A. (1957). Synthesis of cell constituents from C2units by a modified tricarboxylic acid cycle. Nature 179, 988-991. doi: 10.1038/ $179988 \mathrm{a} 0$

Latifi, A., Jeanjean, R., Lemeille, S., Havaux, M., and Zhang, C.-C. (2005). Iron starvation leads to oxidative stress in Anabaena sp. strain PCC 7120. J. Bacteriol. 187, 6596-6598. doi: 10.1128/JB.187.18.6596-6598.2005

Lauro, F. M., McDougald, D., Thomas, T., Williams, T. J., Egan, S., Rice, S., et al. (2009). The genomic basis of trophic strategy in marine bacteria. Proc. Natl. Acad. Sci. U.S.A. 106, 15527-15533. doi: 10.1073/pnas.0903507106

Le Roux, F., Binesse, J., Saulnier, D., and Mazel, D. (2007). Construction of a Vibrio splendidus mutant lacking the metalloprotease gene VSM by use of a novel counterselectable suicide vector. Appl. Environ. Microbiol. 73, 777-784. doi: 10.1128/AEM.02147-06

Le Roux, F., Davis, B. M., and Waldor, M. K. (2011). Conserved small RNAs govern replication and incompatibility of a diverse new plasmid family from marine bacteria. Nucleic Acids Res. 39, 1004-1013. doi: 10.1093/nar/gkq852

Leaden, L., Silva, L. G., Ribeiro, R. A., dos Santos, N. M., Lorenzetti, A. P. R., Alegria, T. G. P., et al. (2018). Iron deficiency generates oxidative stress and activation of the SOS response in Caulobacter crescentus. Front. Microbiol. 9:2014. doi: 10.3389/fmicb.2018.02014

Lemire, A., Goudenège, D., Versigny, T., Petton, B., Calteau, A., Labreuche, Y., et al. (2015). Populations, not clones, are the unit of vibrio pathogenesis in naturally infected oysters. ISME J. 9, 1523-1531. doi: 10.1038/ismej.2014.233
Lesser, M. P. (2006). Oxidative stress in marine environments: biochemistry and physiological ecology. Annu. Rev. Physiol. 68, 253-278. doi: 10.1146/annurev. physiol.68.040104.110001

Marie, D., Partensky, F., Jacquet, S., and Vaulot, D. (1997). Enumeration and cell cycle analysis of natural populations of marine picoplankton by flow cytometry using the nucleic acid stain SYBR Green I. Appl. Environ. Microbiol. 63, 186-193.

Martin, J. H. (1990). Glacial-interglacial CO 2 change: the iron hypothesis. Paleoceanography 5, 1-13. doi: 10.1029/PA005i001p00001

Martin, J. H., and Fitzwater, S. E. (1988). Iron deficiency limits phytoplankton growth in the north-east Pacific subarctic. Nature 331, 341-343. doi: 10.1038/ $331341 \mathrm{a} 0$

Matallana-Surget, S., Cavicchioli, R., Fauconnier, C., Wattiez, R., Leroy, B., Joux, F., et al. (2013). Shotgun redox proteomics: identification and quantitation of carbonylated proteins in the UVB-resistant marine bacterium, Photobacterium angustum S14. PLoS One 8:e68112. doi: 10.1371/journal.pone.00 68112

Matallana-Surget, S., Joux, F., Wattiez, R., and Lebaron, P. (2012). Proteome analysis of the UVB-resistant marine bacterium Photobacterium angustum S14. PLoS One 7:e42299. doi: 10.1371/journal.pone.0042299

Meylan, S., Porter, C. B. M., Yang, J. H., Belenky, P., Gutierrez, A., Lobritz, M. A., et al. (2017). Carbon sources tune antibiotic susceptibility in Pseudomonas aeruginosa via tricarboxylic acid cycle control. Cell Chem. Biol. 24, 195-206. doi: 10.1016/j.chembiol.2016.12.015

Morel, F. M. M., Rueter, J. G., Anderson, D. M., and Guillard, R. R. L. (2008). AQUIL: a chemically defined phytoplankton culture medium for trace metal studies. J. Phycol. 15, 135-141. doi: 10.1111/j.1529-8817.1979.tb0 2976.x

Obernosterer, I., Fourquez, M., Blain, S., Obernosterer, I., Fourquez, M., and Fe, S. B. (2015). Fe and C co-limitation of heterotrophic bacteria in the naturally fertilized region off the Kerguelen Islands To cite this version: Fe and C colimitation of heterotrophic bacteria in the naturally fertilized region off the Kerguelen Islands. Biogeosciences 12, 1983-1992. doi: 10.5194/bg-12-19832015

Oexle, H., Gnaiger, E., and Nter Weiss, G. (1999). Iron-dependent changes in cellular energy metabolism: in uence on citric acid cycle and oxidative phosphorylation. Biochim. Biophys. Acta 1413, 99-107. doi: 10.1016/S00052728(99)00088-2

Oldfelt, C.-O. (1942). CHAPTER 1: relationship between oxygen consumption and growth. Acta Med. Scand. 110, 9-84. doi: 10.1111/j.0954-6820.1942.tb11198.x

Oppenheimer, H. C. (1952). The growth and viability of sixty-three species of marine bacteria as influenced by hydrostatic pressure. J. Mar. Res. 11, 10-18.

Ostrowski, M., Cavicchioli, R., Blaauw, M., and Gottschal, J. C. (2001). Specific growth rate plays a critical role in hydrogen peroxide resistance of the marine oligotrophic ultramicrobacterium sphingomonas alaskensis strain RB2256. Appl. Environ. Microbiol. 67, 1292-1299. doi: 10.1128/AEM.67.3.1292-1299. 2001

Palovaara, J., Akram, N., Baltar, F., Bunse, C., Forsberg, J., and Pedrós-alió, C. (2014). Stimulation of growth by proteorhodopsin phototrophy involves regulation of central metabolic pathways in marine planktonic bacteria. Proc. Natl. Aacd. Sci. U.S.A. 111, E3650-E3658. doi: 10.1073/pnas.14026 17111

Park, S. J., and Gunsalus, R. P. (1995). Oxygen, iron, carbon, and superoxide control of the fumarase fumA and fumC genes of Escherichia coli: role of the arcA, fnr, and soxR gene products. J. Bacteriol. 177, 6255-6262. doi: 10.1128/JB. 177.21.6255-6262.1995

Pinhassi, J., DeLong, E. F., Béjà, O., González, J. M., and Pedrós-Alió, C. (2016). Marine bacterial and archaeal ion-pumping rhodopsins: genetic diversity, physiology, and ecology. Microbiol. Mol. Biol. Rev. 80, 929-954. doi: 10.1128/ MMBR.00003-16

Price, N. M. (1989). Preparation and chemistry of the artificial algal culture medium Aquil. Biol. Oceanogr. 6, 443-461.

Rutter, J., Winge, D. R., and Schiffman, J. D. (2010). Succinate dehydrogenase Assembly, regulation and role in human disease. Mitochondrion 10, 393-401. doi: 10.1016/j.mito.2010.03.001

Sasnow, S. S., Wei, H., and Aristilde, L. (2016). Bypasses in intracellular glucose metabolism in iron-limited Pseudomonas putida. Microbiologyopen 5, 3-20. doi: $10.1002 / \mathrm{mbo} 3.287$ 
Schott, E. J., Pecher, W. T., Okafor, F., and Vasta, G. R. (2003). The protistan parasite Perkinsus marinus is resistant to selected reactive oxygen species. Exp. Parasitol. 105, 232-240. doi: 10.1016/j.exppara.2003.12.012

Schwalbach, M. S., Tripp, H. J., Steindler, L., Smith, D. P., and Giovannoni, S. J. (2010). The presence of the glycolysis operon in SAR11 genomes is positively correlated with ocean productivity. Environ. Microbiol. 12, 490-500. doi: 10. 1111/j.1462-2920.2009.02092.x

Shakoury-Elizeh, M., Protchenko, O., Berger, A., Cox, J., Gable, K., Dunn, T. M., et al. (2010). Metabolic response to iron deficiency in Saccharomyces cerevisiae. J. Biol. Chem. 285, 14823-14833. doi: 10.1074/jbc.M109.091710

Sigel, S. P., and Payne, S. M. (1982). Effect of iron limitation on growth, siderophore production, and expression of outer membrane proteins of Vibrio cholerae. J. Bacteriol. 150, 148-155.

Smith, D. P., Kitner, J. B., Norbeck, A. D., Clauss, T. R., Lipton, M. S., Schwalbach, M. S., et al. (2010). Transcriptional and translational regulatory responses to iron limitation in the globally distributed marine bacterium Candidatus pelagibacter ubique. PLoS One 5:e10487. doi: 10.1371/journal.pone.0010487

Sudarsan, S., Dethlefsen, S., Blank, L. M., Siemann-Herzberg, M., and Schmid, A. (2014). The functional structure of central carbon metabolism in Pseudomonas putida KT2440. Appl. Environ. Microbiol. 80, 5292-5303. doi: 10.1128/AEM. 01643-14

Thimm, O., Essigmann, B., Kloska, S., Altmann, T., and Buckhout, T. J. (2017). Response of Arabidopsis to iron deficiency stress as revealed by microarray analysis 1. Plant Physiol. 127, 1030-1043. doi: 10.1104/pp.010191

Tiwari, B. S., Belenghi, B., and Levine, A. (2002). Oxidative stress increased respiration and generation of reactive oxygen species, resulting in ATP depletion, opening of mitochondrial permeability transition, and programmed cell death. Plant Physiol. 128, 1271-1281. doi: 10.1104/pp.010999

Tortell, P. D., Maldonado, M. T., Granger, J., and Price, N. M. (1999). Marine bacteria and biogeochemical cycling of iron in the oceans. FEMS Microbiol. Ecol. 29, 1-11. doi: 10.1111/j.1574-6941.1999.tb00593.x

Tortell, P. D., Maldonado, M. T., and Price, N. M. (1996). The role of heterotrophic bacteria in iron-limited ocean ecosystems. Nature 383, 330-332.

Val, M.-E., Skovgaard, O., Ducos-Galand, M., Bland, M. J., and Mazel, D. (2012). Genome engineering in Vibrio cholerae: a feasible approach to address biological issues. PLoS Genet. 8:e1002472. doi: 10.1371/journal.pgen.1002472
Vanni, P., Giachetti, E., Pinzauti, G., and McFadden, B. A. (1990). Comparative structure, function and regulation of isocitrate lyase, an important assimilatory enzyme. Comp. Biochem. Physiol. Part B Comp. Biochem. 95, 431-458. doi: 10.1016/0305-0491(90)90002-B

Vattanaviboon, P., and Mongkolsuk, S. (2001). Unusual adaptive, cross protection responses and growth phase resistance against peroxide killing in a bacterial shrimp pathogen, Vibrio harveyi. FEMS Microbiol. Lett. 200, 111-116. doi: 10.1111/j.1574-6968.2001.tb10701.x

Wayne, L. G., and Lin, K. Y. (1982). Glyoxylate metabolism and adaptation of Mycobacterium tuberculosis to survival under anaerobic conditions. Infect. Immun. 37, 1042-1049.

Wayne, L. G., and Sohaskey, C. D. (2001). Nonreplicating persistence of Mycobacterium tuberculosis. Annu. Rev. Microbiol. 55, 139-163. doi: 10.1146/ annurev.micro.55.1.139

Wiens, J. R., Vasil, A. I., Schurr, M. J., and Vasil, M. L. (2014). Iron-regulated expression of alginate production, mucoid phenotype, and biofilm formation by Pseudomonas aeruginosa. mBio 5:e1010-13. doi: 10.1128/mBio.01010-13

Wilcox, R. R. (2012). Introduction to Robust Estimation and Hypothesis Testing. Cambridge, MA: Academic Press.

Williams, T. J., Joux, F., Lauro, F. M., Matallana-Surget, S., and Cavicchioli, R. (2011). "Physiology of marine oligotrophic ultramicrobacteria," in Extremophiles Handbook, ed. K. Horikoshi (Tokyo: Springer), 1179-1199.

Wolfe, A. J. (2005). The acetate switch. Microbiol. Mol. Biol. Rev. 69, 12-50. doi: 10.1128/MMBR.69.1.12-50.2005

Conflict of Interest Statement: The authors declare that the research was conducted in the absence of any commercial or financial relationships that could be construed as a potential conflict of interest.

Copyright (c) 2018 Koedooder, Guéneuguès, Van Geersdaële, Vergé, Bouget, Labreuche, Obernosterer and Blain. This is an open-access article distributed under the terms of the Creative Commons Attribution License (CC BY). The use, distribution or reproduction in other forums is permitted, provided the original author(s) and the copyright owner(s) are credited and that the original publication in this journal is cited, in accordance with accepted academic practice. No use, distribution or reproduction is permitted which does not comply with these terms. 